\title{
THE IMPLEMENTATION OF LESSON STUDY TO IMPROVE STUDENTS' VOCABULARY MASTERY THROUGH TEAM ACCELERATED INSTRUCTION (TAI)
}

\author{
Rulik Setiani *)
}

\begin{abstract}
Abstrak
Untuk meningkatkan mutu pendidikan terutama ditingkat perguruan tinggi STKIP Muhammadiyah Kotabumi dibutuhkan upaya dan usaha tenaga pendidik atau dosen yang dapat memperbarui dan meningkatkan pembelajaran agar hasil belajar meningkat. Salah satu upaya yang dilakukan oleh para dosen, yaitu dengan menerapkan lesson study karena lesson study merupakan suatu proses kolaboratif atau model pembinaan profesi pendidik melalui pengkajian pembelajaran secara kolaboratif dan berkelanjutan berdasarkan prinsip-prinsip kolegalitas dan mutual learning. Untuk membangun learning community dilakukan tiga tahapan, yaitu plan, do, dan see. Dalam tahap plan dosen model menyampaikan lesson design yang sudah dirancang sesuai dengan tujuan pembelajaran pada mata kuliah vocabulary development program studi pendidikan bahasa Inggris semester satu kelas A. Dosen model menyiapkan lembar kerja mahasiswa untuk mengukur tingkat pemahaman terhadap materi yang sudah dipelajari. Pada tahap do melalui model pembelajaran TAI, dosen menyuruh mahasiswa untuk membentuk kelompok beranggotakan 3 sampai 4. Dosen menjelaskan materi pembelajaran, setelah itu setiap mahasiswa pada masing-masing kelompok diberi lembar kerja yang pada awalnya mereka harus mengerjakanya masing-masing dan kemudian mereka dapat berdiskusi dengan sesama anggota kelompoknya. Jika mereka sudah selesai, dosen mengecek hasil kerjanya dengan cara mahasiswa mempresentasikanya ataupun juga dengan dibahas bersama-sama. Dosen jaga memberi apresiasi pada setiap kelompok yang dapat menjawab dengan benar, pada tahap ini dosen lainnya sebagai pengamat mengamati kegiatan mahasiswa selama proses pembelajaran berlangsung. Tahap yang terahir, yaitu see, pada tahap ini dosen model beserta para dosen lain atau para pengamat dipandu dengan moderator menyampaikan temuan-temuan selama proses pembelajaran dan memberikan saran.Hal ini bertujuan untuk perbaikan agar proses pembelajaran pada tahap berikutnya lebih baik dan meningkat.
\end{abstract}

\section{Kata Kunci: Lesson Study, Vocabulary Development, TAI}

\section{INTRODUCTION}

Vocabulary is a gist component of language competency and provides much of the basis for how well students speak, listen, read and write. Students who want to improve their English should master the vocabulary. It used in any situation: it is in the form of spoken and written language.

Without an extensive vocabulary and strategies for acquiring new vocabulary, students often achieve less than their potential and may be discouraged from making use of language learning opportunities around them such as listening 
to the radio, listening to native speakers, using the language in different context, reading or watching television (Richard and Renandy, 2010:255).

In addition, Richard and Renandy (2010:692), vocabulary is a set of lexemes, including single words, compound words and idioms. The writer thinks that vocabulary is one of the important components that have to be mastered by learners. So, they can master English well. Vocabulary is the one thing beside many factors in learning English. Without mastering vocabulary, it is impossible to master English well. The more students get the vocabulary, the easier students improve their English. According to Thonbury (2004:13) without grammar very little can be conveyed, without vocabulary nothing can be conveyed.

Richard and Renandy (2010:4) also explain that "vocabulary is one of the most obvious components of language and one of the first things applied linguists turned their attention to". Based on the definition above, the writer concludes that vocabulary is all the words that have meaning and usually used to communicate by a particular person. To improve their vocabulary mastery, it is not easy, the teacher has to prepare his or her strategy to improve it in order the they can be motivated and the achievement can be raised. There are some ways to improve their vocabulary mastery, one of them is by implementing lesson study through Jigsaw technique.

As stated by Sparks in Mahmudi (2006:1), lesson study is a collaborative process done by a group of teachers to identify some problems occur in learning started by plan, do, and see or reflection. In addition, Dudley (2011:2) said that "lesson study involves groups of teachers collaboratively planning, teaching, observing andanalysing learning and teaching in 'research lessons'. They record their findings. Over a cycle of research lessons they may innovate or refine a pedagogical approach which will be shared with others both through public research lessons, and through the publication of a paper outlining their work".

Teachers can use a variety of teaching techniques in the classroom, one of them is Team Accelerated Instruction (TAI). TAI is one type of collaborative learning that enable the students to be able to comprehend the material in learning. According to Smith and MacGregor (2004), TAI is the combination between cooperative/collaborative learning and individual learning. Step by step, firstly each groups given worksheet that they have to do individually, after that it will discuss together in grouping. if the first worksheet has finished well, each of them do the next worksheet, but if one of them cannot finish the first worksheet well, he or she has ti finish another task at the same worksheet. 
The scoring is based on individual and group.

\section{THEORY REVIEW}

\section{Lesson Study}

Lesoon study involves groups of teachers collaboratively planning, teaching, observing and analysing learning and teaching in 'research lessons'. They record their findings. Over a cycle of research lessons they may innovate or refine a pedagogical approach which will be shared with others both through public research lessons, and through the publication of a paper outlining their work (Dudley (2011:2). He also said that Lesson Study works because it helps teachers to:

- see pupil learning occurring in much sharper detail than is usually possible.

- see the gaps between what they had assumed was happening when pupils learned and what it actually happening.

- find out how to plan learning which is better matched to the pupils' needs as a result.

- do all this in the context of a supportive teaching and learning community which is strongly committed to helping pupils to learn and to the professional learning of themembers of the group. (Dudley, 2011:4). In addition, Sudrajat in Anggara and Chotimah (2012:189), said that lesson study is one of an effort to improve a learning process and learning achievement which are done in collaboratively and contiuously done by a group of teachers.

\section{Process of Lesson Study}

Lesson study is a founding model of teacher profession in implementing the lesson study, there are some stages should be done. According to Rusman in Anggara and Chotimah (2012:191), there are four stages in implementing lesson study:

1) Plan

This stage, the teacher as a model with other teachers collaboratively prepare the lesson plan, lesson design, media, and students worksheet based on the aim of the material which will be taught.

2) Do

In this stage, one teacher as a model teaches based on the lesson design that he or she designs before with other teachers and the other teachers as observers observe the students activity during the learning process and also taking note whatever happened during the learning.

\section{3) See or Reflection}

The last stage is see or reflection, in this stage the teacher as a model with other teachers or observers and moderator meet together to discuss the result of the learning process based on the observation done by some observers, they give some comments and suggestion relates to students' activity during the learning process to make the next learning process to be better. 
The scheme of the lesson study based on the picture below:

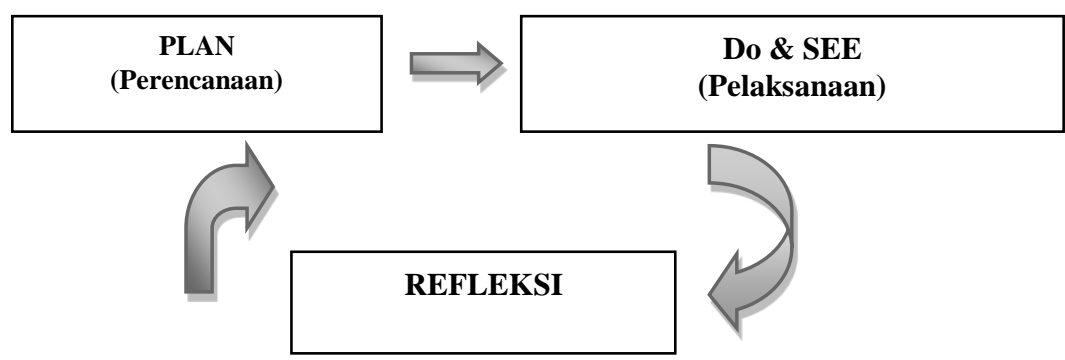

Picture 1. Scheme of Lesson Study (Sukirman in Anggara and Chotimah, 2012:191)

\section{Cooperative Learning}

Teachers can use a variety of teaching methods in the classroom. One type of this method is Cooperative Learning. Cooperative learning is a teaching method that focuses on groups, students with abilities, characteristics, and different backgrounds. According to Johnson \& Johnson in Slavin (2005:23), cooperative learning is the grouping of students in the classroom into a small group for students to collaborate with their maximum abilities and learn from each other in the group. In addition, according to Artz and Newman in Trianto (2009:56) states that the cooperative learning, students learn together as a team to accomplish the tasks the group to achieve a common goal. Therefore, each member of the group has the same responsibility for the success of the group. Referring to the previous statement above it $\mathrm{s}$ believed that a good method that can be used to improve the ability of students to learn during the process of teaching and learning.
Cooperative learning is a learning strategy with a number of students who have different levels of ability in a small group, and each group member is responsible not only to understand what is taught but also to help a friend in the group. Slavin (2005:91) said that teachers should be more active, especially in developing lesson plans, classroom conditions develop current teaching practices, and preparing students to do assignments in their groups. There are several techniques that are involved in the cooperative learning, one of them is Team Accelerated Instruction (TAI).

\section{Team Accelerated Instruction (TAI)}

According to Smith and MacGregor (2004), this learning is the combination between cooperative/collaborative learning and individual learning. Step by step, firstly each groups given worksheet that they have to do individually, after that it will discuss together in grouping. if the first worksheet has finished well, each of them do the next 
worksheet, but if one of them cannot finish the first worksheet well, he or she has ti finish another task at the same worksheet. The scoring is based on individual and group.

\section{DISCUSSION}

Based on the previous theories above, the writer explains the learning process done during open lesson relates with the title " the implementation of lesson study to improve students' vocabulary mastery through TAI", the writer as the lecturer did some stages during open lesson, the stages can be explained as follows.

\section{Plan}

Before the open lesson done, the lecturer prepared lesson plan, lesson design, and students' work based on the material taught in each cycles, then the lecturer met together with collaborators or observers and helped by the moderator, the collaborators or observers observed the students' activities during open lesson done or during learning process, the lecturer as a model delivered the lesson design that she prepared before, and the collaborators gave a comment or suggestion relates to lesson design that designed by the lecturer.

\section{Do}

The next stage is do (open lesson), this stage the lecturer as a model taught based on the plan or lesson design that she designed based on the goal of the learning in three activities, the first activity is pre-activity which consist of 10 minutes (aperception), this activity the lecturer greeted and checked the students and make sure all students have made a group which consist of 3 to 4 students, she delivered the material that taught in three cycles, the first cycle she taught about noun, verb, and adverb, the second is adjective and conjunction, and the third is preposition and pronoun . then in whilts activity which consist of 70 minutes, she delivered the material based on each cycles, and the students in a group given a challenge relates to the topic discussed, the challenge is by given some questions relates to the topic discussed directly, not only that they also given worksheet that should be done individually for the first after that they could discuss with other members in their group or other group. This was done to know whether they have understood or not with the topic. In this activity the lecturer guided them during the discussion. If they finished to do it, the lecturer checked their work together or they could present their work in front of the class. The last is post activity, this activity lecturer concluded the material already discussed and inform to the students about the next material will be discussed in the next meeting. 


\section{See or Reflection}

The last stage is reflection, this stage done after the open lesson is over, the lecturer as a model met again with some collaborators as observers and also moderator to deliver anything that happened during learning process or open lesson done. They give comments or suggestions relates to anything happened during learning process. The purpose is to make the next learning to be better. Based on the comments and suggestion delivered by observers that the first cycle some of groups seem to be active but some of still passive, but it was a progress on the second cycle, the students who are not active in the first cycle they have looked more active in the second cycle, for the third cycle they looked more active and antusiastic during learning process, it can be seen when they want to try to answer each other.

\section{CONCLUSION}

Based on the previous discussion, the writer concludes that by implementing lesson study, it gives many benefits, the students became active, motivated, and antusiastic during learning process not only that their mastery of vocabulary is improved. So, by implementing lesson study give positive impact not only for teachers or lecturers as a model but also for collaborators or observers, they can get lesson learned directly from what they observe, it can also help their learning to be better.

\section{REFERENCES}

Anggara, Rian and Chotimah, Umi. 2012. Penerapan Lesson Study Berbasis Musyawarah Guru Mata Pelajaran (MGMP) Terhadap Peningkatan Kompetensi Profesional Guru Pkn SMP Se-Kabupaten Ogan Ilir. Universitas Sriwijaya.

Dudley, Pete. 2011. Lesson Study: a Handbook. United Kindom.

Mahmudi, Ali. 2006. Lesson Study. Yogjakarta: UNY.

Richard, Jack and Renandy, Willy. 2010. Methodology in Language Teaching. USA: Cambridge University Press.

Slavin E, Robert. 2005. Cooperative Learning: Riset dan Praktik. Bandung: Nusa Media.

Smith and MacGregor. 2004. Collaborative Learning.

Thornbury, Scott. 2004. How to each Vocabulary. Charlbury: Bluestone Press.

Trianto. 2009. Mendesain Model Pembelajaran Inovatif-Prorgresif. Jakarta: Kencana Prenada Media Group. 